Revista Iberoamericana, Vol. LXXIII, Núm. 218, enero-marzo 2007, 13-27

\title{
CATEDRALES, NÓMADAS Y CUERPOS SIN ÓRGANOS: ENTRE GILLES DELEUZE Y LAS NOVELAS DE MOGADOR DE ALBERTO RUY SÁNCHEZ
}

\author{
POR \\ Michael Abeyta \\ Colorado State University
}

No se deberá preguntar nunca lo que un
libro quiere decir, significado o significante;
tampoco deberá tratarse de comprendernada
en un libro. Únicamente vale preguntar con
qué funciona; en conexión de qué hace
pasar o no intensidades; en cuáles
multiplicidades introduce y metamorfosea
la suya; con qué cuerpos sin órganos hace
converger el suyo.
Gilles Deleuze y Félix Guattari

I. INTRODUCCIÓN

Hace varios años Alberto Ruy Sánchez ofreció una conferencia en la Universidad de California en Davis sobre la melancolía en la literatura. Aquella fue la primera vez que lo escuché, pero lo que más me atrajo fue cuando comparó sus novelas con las catedrales góticas en el sentido en que las describen Gilles Deleuze y Félix Guattari. En ese momento yo estaba leyendo Mil mesetas de Deleuze y Guattari, en donde postulan la relación entre las catedrales y la nomadología. Me intrigó la comparación de Ruy Sánchez: ¿Cómo podría ser una novela como una catedral? y ¿qué tiene que ver con los nómadas? Las novelas de Ruy Sánchez son como catedrales porque son ensambladuras, anti-estructuras dinámicas en donde es menos importante la forma o estructura total que las interconexiones entre fuerzas, segmentos, líneas, e intensidades. Así definen Deleuze y Guattari a las catedrales:

éstas representan una arquitectura dinámica en donde la relación estática entre la materia y la forma, evidente en la arquitectura románica, es desplazada por la relación dinámica entre la materia y la fuerza. Ya no es la forma gruesa del muro que apoya las bóvedas, como en las iglesias románicas, sino que en la catedral gótica la estructura depende del corte de la piedra que conecta líneas capaces de coordinar mejor las fuerzas de tensión y gravedad en las columnas. Esto produce mayor dinamismo en el espacio, lo cual permite bóvedas más altas y más largas. (Mil mesetas 370-71) 
Es decir, lo minúsculo, el corte de la piedra, abre el espacio permitiendo mayor expansión y mayor dinamismo. Esto dependía a su vez de la artesanía de los constructores que pertenecían a gremios nómadas y que construían por piezas, usando una geometría arquimediana algo improvisada. ${ }^{1}$

En sus novelas Ruy Sánchez busca la misma fluidez dinámica que se encuentra en las catedrales góticas y que depende de los componentes mínimos de la ensambladura, de la conectividad entre ellos. Como entre los obreros que levantaban las catedrales, la geometría de la narrativa de Ruy Sánchez no se extiende desde una estructura total, sino que depende de la posibilidad conectiva de lo que él llama las intensidades, imágenes poéticas que tendrían la misma función que los cortes de los constructores de las catedrales. Por eso, Ruy Sánchez suele comparar sus narraciones con la artesanía.

Las novelas del autor mexicano que estudiaremos aquí son Los nombres del aire (1987), En los labios del agua (1996), y Los jardines secretos de Mogador (2001), las cuales ubican casi toda su narración en la ciudad de Essaouira en Marruecos, que también es conocida por su antiguo nombre de Mogador. Conforman parte de una "tetralogía del deseo"; la última novela, Las manos del fuego, todavía no se ha publicado. Como se puede apreciar en los títulos, en el sistema semiótico de cada novela predomina uno de los elementos fundamentales: el aire, el agua, la tierra y el fuego. Lo que proponemos mostrar en este estudio es que las novelas de Ruy Sánchez y el discurso filosófico de Deleuze comparten algunos de los mismos principios: a saber, los principios de conexión, movilidad, fluidez, plasticidad y heterogeneidad.

En las novelas de Ruy Sánchez, la composición narrativa se engendra en la fluidez de las intensidades poéticas, las imágenes poéticas y sensuales, a la vez que se organiza como ensambladura. La arquitectura de sus novelas se relaciona más con la música, el

\footnotetext{
${ }^{1}$ Para Deleuze y Guattari esta geometría arquimediana se asocia con la nomadología, una especie de anti-ciencia estudiada en Mil mesetas. Según Deleuze y Guattari, la oposición entre la ciencia nómada y la ciencia real, que se asocia con los Estados, se explica precisamente en el trabajo de estos gremios nómadas, o compagnonnages. "Son bien conocidos los problemas que siempre han tenido los Estados con los 'compagnonnages', los cuerpos nómadas o itinerantes del tipo albañiles, carpinteros, herreros, etc. Fijar, sedentarizar la fuerza del trabajo, regular el movimiento del flujo de trabajo, [...], y, para lo demás, recurrir a una mano de obra forzosa, reclutada in situ (corvea) o entre los indigentes (talleres de caridad), -esa fue siempre una de las tareas fundamentales del Estado, con la que se proponía a la vez acabar con un vagabundeo de banda y un nomadismo de cuerpo-. Si volvemos al ejemplo gótico es para recordar lo mucho que viajaban los compagnons, construyendo catedrales aquí y allá, diseminando las obras, disponiendo de una potencia activa y pasiva (movilidad y huelga) que evidentemente no convenía a los Estados. La respuesta del Estado es dirigir las obras, introducir en todas las divisiones del trabajo la distinción suprema de lo intelectual y lo manual, de lo teórico y lo práctico, copiada de la diferencia 'gobernantes-gobernados'. Tanto en las ciencias nómadas como en las ciencias reales encontraremos la existencia de un 'plan', pero que en modo alguno es el mismo. Al plano sobre el suelo del compagnon gótico se opone el plano métrico sobre papel del arquitecto exterior a la obra. [...] A la talla por corte a escuadra de las piedras se opone la talla por paneles, que implica la construcción de un modelo reproducible. No sólo se dirá que ya no se necesita un trabajo cualificado: se necesita un trabajo no cualificado, una descualificación del trabajo" (Mil mesetas 374). De ahí la valorización en la narrativa de Ruy Sánchez del trabajo artesanal, de las intensidades poéticas-afectivas y de la ciencia nómada frente a la estructura estática y el discurso teórico.
} 
mosaico, la caligrafía, y las artes plásticas que con las convenciones tradicionales de la novela, el suspenso y la anécdota. Ruy Sánchez llama a este estilo "la prosa de intensidades", o la poesía en prosa, que implica "la búsqueda en la literatura de dimensiones poéticas ocultas en la cotidianidad” (Paúl Arranz 365). También recuerda la orfebrería marroquí, como señala Oumama Aouad Lahrech: “Tejidos de aire y sueño, estos textos, más poéticos que novelísticos, están escritos en una 'prosa de intensidades', ... escritura-filigrana, parecida a la orfebrería de Essaouira" ("Mogador, puente colgante”). Ruy Sánchez elabora el concepto de "la prosa de intensidades" a través de la lectura de varios precursores, entre los que se destacan Rilke, Nietzsche,Yourcenar, Klossowski, Beckett y Martínez Sotomayor. En Al filo de las hojas, Ruy Sánchez nos ofrece Las ruecas de aire de Martínez Sotomayor como ejemplo de la prosa de intensidades. Para Ruy Sánchez el valor de esta novela no reside en la anécdota de su argumento, sino en "su fluida arquitectura de imágenes poéticas” (Al filo 74). Pero volveremos a este concepto y su importancia después de establecer la relación entre la narrativa de nuestro autor y el discurso filosófico de Deleuze y Guattari.

Señalan María del Mar Paúl Arranz y María Luiza de la Garza Chávez que las novelas de Ruy Sánchez también siguen una composición rizomática en el sentido deleuziano: “en una concepción de la escritura que recuerda al rizoma de Deleuze y Guattari, los símbolos de Ruy Sánchez eslabonan régimenes distintos y establecen correspondencias entre dimensiones diferentes; por ello, lo que ocurre en el cuerpo repercute en la ciudad ... y los movimientos de los astros sugieren caminos si se acierta a interpretarlos" (360). Como es bien sabido, Ruy Sánchez fue estudiante de Deleuze (y también de Roland Barthes) durante varios años en París; por consiguiente es lógico que habría una relación intertextual con el discurso filosófico de Deleuze, que favorecía la mónada y la ensambladura, el movimiento fluido y la velocidad. No pretendo ofrecer aquí una lectura exclusiva ni única: ha habido ya bastante escrito sobre la obra de Ruy Sánchez, y hay siempre muchas lecturas posibles. Pero sí, queremos examinar los puntos de conexión entre los dos autores, contestar la pregunta del epígrafe de Deleuze: “¿en conexión de qué hace pasar o no intensidades; en cuáles multiplicidades introduce y metamorfosea la suya?” Veremos que los dos autores comparten algunas preferencias y principios que cobran fuerza poética en la escritura de Ruy Sánchez. En lugar de recontar las tramas de las tres novelas- Los nombres del aire, En los labios del agua y Los jardines secretos de Mogador-quisiera discutir simplemente tres conceptos que comparten la filosofía de Deleuze y la escritura novelística de Ruy Sánchez; a saber, la nomadología, la prosa de intensidades y el cuerpo sin órganos.

\section{LA NOMAdOlOGía Y LOS ÁMBitos De MogadoR}

En su breve ensayo sobre Los nombres del aire, "La emigración de los tatuajes", Severo Sarduy afirma que la narrativa de Ruy Sánchez consiste en una "semiología de la movilidad” y una "heráldica del desplazamiento" (1434). En la estética de las novelas de Mogador se favorece el principio de la movilidad en la selección de símbolos, leitmotivs, signos y en la arquitectura misma de la narrativa. En cada novela los viajes de los personajes, tanto interiores como exteriores, son de suma importancia: Kadiya en Los 
nombres proviene de una comunidad nómada y huye de la matanza general de su gente; Fatma deambula en la ciudad en búsqueda ciega de Kadiya; Juan Amado en En los labios emprende un viaje de México a Mogador en la búsqueda de un deseo oculto; el protagonista de Los jardines se ve obligado a recorrer las calles de Mogador en busca de jardines secretos. La experiencia nómada cobra intimidad en la vida de los personajes, y se relaciona con la nomadología, una especie de anti-ciencia estudiada por Deleuze y Guattari en Mil mesetas.

La nomadología para estos dos autores representa toda una manera de vivir y de pensar, una especie de antiepistemología basada en el cambio permanente y en una visión peculiar del espacio y de cómo se vive. En este sentido, según Dardo Scavino, "la nomadología implica una filosofía del movimiento y del devenir, de la aceleración y del cambio, de lo mutante y de lo efímero" (15). Para ser nómada, según Deleuze y Guattari, uno tiene que producir y moverse en lo que ellos llaman espacios lisos. Estos son espacios algo caóticos, que no se organizan en base a una estructura o a una jerarquía; son los desiertos, los océanos y las llanuras en donde hay infinitas líneas de fuga, energías voraginosas e intensidades localizadas. Se oponen a los espacios estriados que son organizados y delineados por el Estado. Las ciudades son buenos ejemplos de esto; muchas veces tienen el patrón de una reja o una red y se organizan alrededor de un centro político. Pero uno puede ser nómada en la ciudad al buscar y crear espacios lisos. Y en las novelas de Mogador, la ciudad misma se organiza en la forma de espiral y promueve la producción de espacios lisos; además, está junto al mar, con sus vientos que corren por la ciudad amurallada, y llegan nómadas tanto del mar como del desierto. Este espacio fluido también compone un espacio social.

Se trata de una tribu ligada a un espacio específico, pero uno que a su vez se adapta a la tribu en movimiento constante dentro de los límites de la ciudad. Esta característica queda muy marcada en las novelas de Mogador, sobre todo en la manera en que sus personajes se ofrecen como líneas de fuga para los deseos de los habitantes de Mogador, como ligadura afectiva. (El término “líneas de fuga” también se asocia con lo que Deleuze y Guattari llaman “desterritorialización”.) El narrador de En los labios del agua emplea este término "líneas de fuga” directamente al referirse a un taller de escritores que dirigía. Dice:

Lo más extraño para mí es que, aquel fin de semana largo ... me convertí en una especie de pararrayos de una peculiar tormenta colectiva de deseos. Fui el visitante amoroso de los cuentos orientales... el pretexto para expresar sus acumulados delirios deseantes. Fui la línea de fuga de su imaginación erótica. Y fui muy feliz con ello. (81)

En una conferencia que dio en San Francisco, Ruy Sánchez ha indicado que esto es la meta de su producción literaria, además de su labor editorial como director de Artes de México: hacer que fluyan los deseos de los lectores (Conferencia sobre Artes de México, Consulado de México, 12 de junio 2003).

En Los nombres del aire, Fatma también sirve como pararrayos para los deseos de los habitantes de Mogador, a la vez que ellos también son líneas de fuga para su imaginación. En el siguiente pasaje vemos también la idea de un espacio liso que es a la vez cuerpo social donde todos sienten en Fatma la fuerza secreta de su interior: 
Para los habitantes de Mogador, Fatma se convirtió pronto en algo más lejano que un cuerpo extranjero. Conociéndola la desconocían, y ya sin poder saber lo que ocultaban sus pensamientos, quienes la veían depositaban en ella una parte de los suyos: los irritables la veían muy irritada, los friolentos aseguraban que tenía pulmonía, los temerosos de perder sus cosas se preguntaban de qué robo habría podido ella ser cómplice, los comerciantes buscaban saber a quién se había vendido con tan malos resultados, y quienes no olían en ella culpas precisas se vaciaban de todas maneras el pensamiento adivinando la humedad atrayente de los pliegues entre sus piernas. (26)

En este pasaje Fatma es como un conducto para los deseos de los habitantes de Mogador, deseos que se intensifican cuando contemplan el misterio del deseo secreto de ella. En este sentido Fatma se vuelve una línea de fuga para la imaginación erótica del pueblo. Esta relación se refleja muy bien el epígrafe de la novela de Marguerite Yourcenar, que dice: "Sin saberlo, todos entramos en los sueños amorosos de quienes se cruzan con nosotros o nos rodean. Y sucede a pesar de la fealdad, la penuria, la edad o la sordidez de quien desea; y a pesar del pudor o la timidez de quien es codiciado, sin que cuenten sus propios deseos, dirigidos tal vez a otra persona. Así, cada uno de nosotros abre a todos su cuerpo y a todos se lo entrega”. Todos somos posibles pararrayos para los flujos de deseo de otros.

No obstante, aunque en cierta manera la gente de Mogador se apropia de la imagen de Fatma para construir sus fantasías conforme a sus propios deseos, no logra conocer el secreto de ella y los que la persiguen amorosamente nunca llegan a poseerla. Con todo, los flujos de deseo estimulados por Fatma conforman un mapa afectivo que puede definir una ciudad.

La ciudad, para la gente de Mogador, era imagen del mundo; un mapa la vida tanto externa como espiritual de los hombres. En la muralla circular, cuatro torres sobre cuatro puertas señalaban los puntos cardinales: "el orbe entero cabe en una nuez, si se sabe elegir el garabato que lo representa”, afirmaba en Mogador un proverbio muy respetado. En cada uno de sus giros La Via luce una fuente. Ellas insinúan que el agua corre por la espiral hasta los baños de hamman, lavándolo todo y a todos. (Los nombres 17-18)

En Con la literatura en el cuerpo Ruy Sánchez hace hincapié en el mapa afectivo de París que Rilke elabora en sus escritos: postula la idea de un cuerpo múltiple, colectivo, o un espacio afectivo de la gente de una ciudad. (Al igual que en Rayuela, la variabilidad de los espacios lisos y a veces el caos son lo que permite los encuentros arbitrarios, como los de Horacio y La Maga.) En "Rilke y Malte en París: vidas y letras góticas” (Con la literatura) Ruy Sánchez emplea la imagen de la catedral para mostrar el ámbito afectivo de París, sobre todo la melancolía asociada en la literatura con la sombra oscura de Notre Dame y el ambiente hospitalario de esa zona. La catedral sirve como parrarayos para los melancólicos:

Hasta el siglo pasado los edificios de L'Hotel Dieu rodeaban casi completemente a la catedral y se extendían hasta la orilla izquierda del Sena. Incluso el puente descubierto que ahora lleva de esa orilla hacia la catedral era una construcción de dos pisos sobre el río formando parte de los multiplicados edificios que daban a la zona central de París un 
extraño ambiente de hospital, el cual como Rilke ya lo dice, no dejará de estar presente en los poetas franceses del siglo xix. Ese hospital, un pulpo alrededor de la catedral, confirmaba a Notre Dame como centro imantado de los que viajaban bajo el signo de la disminución de la vida. ¿Cómo extrañarse de que sea aún para los melancólicos lugar de morbosa peregrinación, tentación de los suicidas, o simplemente quimera para los que navegan en las fronteras de la razón? (40-41)

La catedral, y por extensión lo gótico, se presencia como una intensidad localizada que manifiesta la melancolía de la experiencia diaria. En este sentido, Ruy Sánchez cartografía el ámbito afectivo de París cuando relata las experiencias íntimas y literarias de los autores y de la gente, sobre todo cuando se expresan por medio de su relación con las catedrales. De su lectura de Los cuadernos de Malte Laurids Briggs de Rainer Marie Rilke, Ruy Sánchez llega a unas conclusiones iluminadoras sobre la presencia de lo terrible en París: "Lo gótico como experiencia cotidiana de lo terrible se ha solidificado en París, ahí tiene su arte y su geografía. Lugares y objetos que condicionan las oscilaciones afectivas de la ciudad, cauce y puentes del río de intensidades en el que Malte Laurids Briggs se ahogó” (43).

En las novelas de Mogador son comunes también los signos de flujo y movilidad como los ríos de “intensidades", el viento, las caravanas, las peregrinaciones, y los barcos que contribuyen de la misma manera a la formación del ámbito afectivo de la ciudad. Los personajes principales emprendan viajes tanto interiores como exteriores en busca de otro cuerpo, otra persona, otro modo o vector para conseguir lo que desean. Y son impulsados por fuerzas fluidas que no siempre reconocen, como los melancólicos o los Sonámbulos de En los labios. En Los nombres del aire, el deseo misterioso que siente Fatma es el viento que la conduce a Kadiya, y resulta que ésta se asocia con el aire por su voz y por su calidad de nómada: En En los labios del agua, Juan Amado se da cuenta de que es de alguna manera poseído por el espíritu o el deseo residuo de un calígrafo muerto, y de que pertenece a una casta de "Sonámbulos", personas hipersensibles al deseo. Aprende que los Sonámbulos son "cuerpos poseídos por los deseos hambrientos de miles de otras personas que murieron antes de realizar sus sueños. Somos enjambres de sueños, enredaderas de sueño, muchas veces con espinas. Nudos de sueños. Por eso estamos aquí, cumpliendo deseos de personas que no conocimos pero que ahora son deseos nuestros" (93). En el capítulo anterior nos informa que "en las corrientes de aire del deseo, el Sonámbulo es a veces como un pez en flujos de agua que no ve pero siente” (83).

Los personajes de estas novelas son impulsados por flujos de deseo que interpenetran muchas vidas, que son las corrientes en el espacio colectivo. En Los jardines secretos de Mogador, el protagonista, nieto de Juan Amado, tendrá que emprender la búsqueda de jardines que no existen: su esposa Jassiba le obliga a aprender una nueva manera de sentir las cosas. Él se vuelve una especie de Scherezade masculino, obligado a convertirse en voz poética y descifrar los jardines ocultos en donde encuentra intensidades localizadas. Uno de los primeros jardines que encuentra está en la mano de una mujer. Dice:

Me extendió la palma de su mano con ademán de orgullo y coquetería. Me sorprendió. Sus tatuajes de jena eran como los de Jassiba pero con un diseño diferente, le cubrían las manos, una parte de la muñeca y el incio del brazo. Su geometría aparentemente sencilla 
era muy compleja. Había formas aisladas y pasajes entre ellas. Me explicó que ese dibujo en particular se llamaba el Jardín de los Orígenes: “Al llevarlo recordamos que cada día debemos construir paraíso con nuestras manos. Aquí está señalado el deber de hacer placenteros los días a quienes nos rodean y a nosotras. Y debemos perseguir con la obstinación de un puño cerrado nuestros deseos”. (81-82)

Además de crear flujos del deseo entre ellas mismas y los demás, las manos descentran las nociones tradicionales del orígen y del paraíso: éste llega a ser móvil, cosa de todos los días, efímero y accesible en los placeres cotidianos. Un paraíso que hay que construir todos los días, como afirmó Ruy Sánchez en una entrevista que tuve con él cuando le pregunté sobre estas manos tatuadas: "lo que está implícito ahí es la idea de que el paraíso no se conquista una vez y para siempre; te lo tienes que ganar cada día, y pensando que el paraíso es el cuerpo de la amada te lo tienes que ganar cada día. Cada día es distinto y hay que ganarlo de nuevo" (Entrevista personal). El narrador de Los jardines añade lo siguiente: “... todos somos hijos del deseo y habitantes del aire, del agua, del fuego y del jardín. El jardín original renace cada vez que lo trazamos con jena en las manos” (83). Este tipo de desplazamiento semiótico, el concepto tradicional del paraíso transformado en una nueva asociación con el tatuaje, se encuentra en las tres novelas y es una característica fundamental del estilo de Ruy Sánchez. Severo Sarduy decifró este desplazamiento en Los nombres cuando dijo: "Ya que si los signos-los de tinta y los otrosemigran contínuamente en el relato, se desplazan de un soporte a otro, donde se entregan a un diferente sentido y a una nueva constelación” (1432).

\section{LA PROSA DE INTENSIDADES COMO ENSAMBLADURA: MOSAICO, CALEIDOSCOPIO, RIZOMA}

Como sus novelas no siguen los patrones usuales de la narrativa occidental, en muchas ocasiones Ruy Sánchez ha sentido la necesidad de explicar o defender la prosa de intensidades. Para Ruy Sánchez, "la prosa de intensidades” es “el nombre genérico que yo quise dar a una composicion que no se base en el suspenso, sino en momentos de intensidad que no son expresables en terminos racionales sino afectivos” (Entrevista personal). También, en una entrevista con Angel Gurría Quintana, Ruy Sánchez afirmó la relación que tiene su narrativa con la herencia artesana, pero también poética, de la cultura magrebina e hispano-árabe: "He querido que la novela sea como un azulejo árabe -un zelije-, cada una de cuyas piezas separadas funcione por sí misma. Al mismo tiempo, todas unidas forman parte de un juego de geometrías más complejo” (Gurría Quintana 10). Y de ahí la comparación con las catedrales en los dos sentidos que hemos visto: 1) como ensambladura cuya geometría depende sobre todo de la artesanía y 2) la catedral como expresión y mapa afectivo de una ciudad. También en Al filo de las hojas, Ruy Sánchez afirma la prevalencia de la imagen como motor de la narración: "la intensidad, para comunicarse, se tiene que volver imagen: como la prosa poética, que avanza por medio de imágenes y no por anécdotas que se encadenen y transcurren a lo largo de una historia” (65).

Esta manera de escribir recuerda el gusto por la mónada y la ensambladura en la filosofía de Deleuze. La escritura de estas novelas es fluida y rizomática, permitiendo así la interconexión de "intensidades", elementos semióticos muy diversos. De ahí, como 
hemos visto, predominan en las novelas los espacios lisos y las imágenes fluidas del aire, el viento, el mar, los peces, la espiral, pero también imágenes de multiplicidades y colectividades nómadas: manadas de aves y lobos, el cuerpo como enjambre de sueños ajenos, barcos que van y vienen, caravanas, y por supuesto las tribus nómadas. (Varios de estos ejemplos figuran en el discurso de Deleuze y Guattari para respaldar los argumentos y planteamientos que favorecen los prinicpios de fluidez, velocidad y multipicidad en contra de la fijación y la individualidad restrictiva).

Es más, por medio de sus narradores Ruy Sánchez nos explica la forma de la novela a través de imágenes, analogías y metáforas: el mosaico, los azulejos, los tatuajes, etc. Cada novela tiene un índice completo y al comienzo se anuncian los pasos que van a tomar sus protagonistas, pero estos elementos estructurales aparentemente fijos sirven para que predomine el flujo de intensidades. En las primeras páginas de Los nombres del aire la abuela de Fatma dispone las cartas de una baraja en forma de espiral para descifrar el destino de Fatma, el sendero en el que le llevará un deseo oculto, cuyo origen es el aire. También, como hemos visto, la ciudad es una espiral: la calle principal conduce en forma de espiral hacia el centro de la ciudad donde se ubica el hammam, los baños públicos en donde Fatma encuentra a Kadiya, su amada. La espiral es insistente en la narrativa: "Sin saberlo, Fatma ya era presa de una geometría implacable: era un punto con destino, una línea del arabesco universal; era un dibujo de espuma en el mar del deseo, una marea callada obedeciendo a la luna” (70). Dicha geometría y los flujos de intensidades desbordan las divisiones convencionales entre los capítulos.

La segunda novela, En los labios del agua, ofrece como modelo la imagen del caleidoscopio: muchas piezas pequeñas que se organizan de infinitas maneras y en todas quedan implícitas las formas del mosaico y la filigrana. El narrador afirma esta idea, añadiendo un matiz muy importante para la comprensión de la prosa de intensidades como escritura rizomática. Dice: "Y era seguro que a partir de esa tarde todo de nuevo se acomodaría de otra manera. La vida, y especialmente la vida de las pasiones, es como un caleidoscopio. Alguien mueve los espejos y somos otros en los afectos de todos los que nos rodean. Entonces ya nada puede ser contado de la misma manera” (En los labios 19). El caleidoscopio introduce el principio del cambio perpetuo, un dinamismo, una mutabilidad inherente en la ensambladura que produce los flujos de intensidades y los ámbitos afectivos.

En Los jardines secretos de Mogador encontramos la búsqueda laberíntica de una serie de jardines que a la vez recuerda Las mil y una noches. El embarazo de Jassiba intensifica los deseos de ella, pero su amante no ha podido seguir los cambios continuos de su cuerpo y su deseo. Ante esta insensibilidad ella le impone un reto: sólo volverán a hacer el amor cada vez que él encuentre un nuevo jardín de Mogador. Pero no hay más jardines y no le permite inventarlos; tiene que descubrirlos donde no son evidentes y luego contárselos a ella. ${ }^{2}$ Cada jardin que encuentra representa un desplazamiento, una intensidad

\footnotetext{
${ }^{2}$ Esta tercera novela es la que tiene relación más directa con Las ciudades invisibles de Italo Calvino, tal vez por su estructura y la manera en que Marco Polo va inventando ciudades. La diferencia clave es que el marido de Jassiba en Los jardines no puede inventar jardines, mientras que Marco Polo sí inventa ciudades. Pero esto casi no importa porque el efecto es parecido: ambos tipos de imágenes,
} 
poética donde se combinan elementos semióticos de diferentes régimenes o dimensiones. El primer jardín que encuentra, como hemos mencionado, lo halla en el diseño de la mano tatuada de jena cuya "geometría aparentemente sencilla era muy compleja. Había formas aisladas y pasajes entre ellas”. Para destacar la combinación de elementos semióticos de diferentes regímenes, Ruy Sánchez inserta la fotografía de una mano tatuada para complementar la imagen textual. El discurso narrativo también refleja esta misma combinación de elementos dispares, artesanos, que aumentan las intensidades. Lo que es más: el amante se convierte en una voz poética que compone proemas (poemas breves escritos en prosa). La novela toma la forma de la risala en donde se mezcla prosa con poesía al estilo de Ibn Hazm de Córdoba y su El collar de la paloma. Se incluyen también otras fotografías y caligrafías que dialogan con la narrativa y fortalecen el aspecto de caleidoscopio, collage, azulejo, jardín, en una palabra: ensambladura.

Lo que les da cohesión a estas novelas no son tanto los fragmentos organizados alrededor de números, sino los elementos y las intensidades producidas por la imagen poética y los flujos del deseo. Los capítulos están cuidadosamente enumerados, pero son las imágenes que nos captan y que requieren otra manera de leer. Como el caleidescopio no tiene estructura fija, al menos esto es lo que se pretende; tiene prioridad la fluidez combinatoria. Se trata de una escritura rizomática en la que las estructuras se desintegran a la vez que se integran. El proceso transfomacional entre flujos y estructuras se ve claramente en un pasaje de Los nombres, cuando Fatma se detiene a observar a unos chicos intentando captar la sal de los muros:

Mientras cruzaban la ciudad cien rumores, el viento de la tarde removía la sal sedimentada durante el año sobre la muralla, levantando de la piedra largas y delgadas hojas blancas. Los niños corrían a recibirlas en el momento en que las hojas de sal se desprendían del muro, y regresaban a sus casas caminando lentamente con las frágiles láminas sobre las manos. Nunca llegaban, porque el mismo viento que se las había entregado se las arrebataba, y al ponerlas a volar las convertía en polvo tan delgado que ni siquiera era posible diferenciarlo del aire. (22)

Al principio parece una imagen metafórica de la desintegración, pero es más que esto: la sal viene del mar, espacio liso, viaja por el aire, forma una estructura que, al ser tocada, se disuelve otra vez en el viento, que es el flujo principal del deseo a través de la novela. Como "intensidad", el aire se concentra en imágenes que toman "corpúsculo", pero que luego fluyen otra vez por los cuerpos y los espacios. La intensidad poética en las novelas de Ruy Sánchez recuerda lo que José Lezama Lima escribiera sobre la poesía de Góngora en su ensayo "Sierpe de don Luis": el poeta "tenía principalmente de los árabes, el secreto deseo en su poesía de llevar una especie, una viviente irradiación a otro elemento de estructura, para sensualizar el verso, convirtiéndolo en un corpúsculo" (“Sierpe” 202). Se trata de una prosa poética que, muy como la poesía barroca, intenta conmover las pasiones del lector a través de la imagen y no tanto a través de los contenidos o la anécdota.

la ciudad y el jardin, transmiten intensidades poéticas basadas en la reconstrucción nostálgica de una experiencia vivida con el propósito de conmover al narratario y al lector. Los efectos de los jardines, sin embargo, son más sensuales y eróticos. 
IV. EL EROTISMO Y EL “CUERPO SIN ÓRGANOS”

La escritura sensual y erótica de Ruy Sánchez comparte con el pensamiento deleuziano una concepción radical del cuerpo humano y su relación íntima con el mundo. Según Francisco José Martínez Martínez, en el pensamiento de Deleuze y Guattari el cuerpo sin órganos se entiende como un "espacio indiferenciado e intensivo";

Tenemos, pues, dos lecturas del mundo, una extensiva, que agrupa los individuos en los diversos estratos, y otra intensiva, que reparte intensidades singulares en un espacio indiferenciado que recibe el nombre de "Cuerpo sin Organos", utilizando aquí este concepto empleado ya por Artaud para referirse a un cuerpo indiferenciado por oposición al organismo, concebido éste como un conjunto de órganos jerarquizado y estructurado. El plano de consistencia es un espacio intensivo, una gigantesca Máquina abstracta que distribuye dispositivos concretos que, a su vez relacionan unos estratos con otros.... (4849)

Este cuerpo sin órganos se integra al mundo; penetra otros cuerpos y es penetrado. Es un cuerpo que se eslabona con otros cuerpos; en este sentido es indiferenciado. La idea del cuerpo como máquina rompe con la concepción dualista entre mecanismo y vitalismo, y la separación entre interior y exterior; se trata más bien de "una mecanosfera, cuyas partes son dispositivos concretos que organizan elementos intensivos, es decir, en última instancia flujos de deseo.... el mundo no es un organismo, sino una máquina, pero las partes de esta máquina no son elementos mecánicos, sino flujos intensivos, deseantes” (Martínez Martínez 48-49). El cuerpo sin órganos se conecta con otros cuerpos a través de objetos parciales: las manos, la mirada (el ojo), los labios, la voz, el ano, pero también con cualquier objeto que produce flujos de deseo, lo que Deleuze y Guattari llaman máquinas deseantes. El modelo arquetípico de los objetos parciales son los labios del bebé que se conectan con el pezón para producir un flujo de leche. El bebé no siente el pezón como relación personal con la madre, sino como un objeto que produce un flujo ( $L$ 'AntiEdipe 55). ${ }^{3}$

En el erotismo de Ruy Sánchez la mirada y las manos sobre todo son los conductores de los flujos de deseo. En Los nombres, y lo mismo vale para los personajes femeninos de En los labios y Los jardines, la mirada de Fatma muchas veces importa más que cómo la ven, lo cual quiere decir que Ruy Sánchez no permite que su erotismo se reduzca al voyeurismo. ${ }^{4}$ Sí, Fatma es objeto de deseo de muchos, como pararrayos de su imaginación

\footnotetext{
${ }^{3}$ Deleuze y Guattari rechazan el complejo de Edipo como modelo represivo del deseo; siguiendo el pensamiento de Antonin Artaud, el deseo para ellos no depende de la relación paternal. En las novelas de Ruy Sánchez, sobre todo en Los nombres, se evita cualquier explicación edípica para representar el deseo entre los personajes.

${ }^{4}$ Sobre el problema de la mirada masculina y la representación de la mujer en la narrativa de Ruy Sánchez, Oumama Aouad Lahrech ha dicho: "Cabe decir que son excepcionales los casos de autores masculinos capaces de captar con tanta sensibilidad y tanta sutileza la intimidad feminina. Uno de ellos es sin duda Flaubert, ejemplo magistral en la literatura universal. Los nombres del aire se sitúa pues en la línea de Madame Bovary; parafraseando al escritor francés en su famosa declaración acerca de su personaje femenino, podemos hacer decir al escritor mexicano: 'Fatma soy yo' Es así
} 
erotica como hemos visto, pero muchas veces ella sólo responde a su propio deseo. A lo largo de la novela Fatma siente una atracción invisible, desconocida, que resulta ser una mujer nómada, Kadiya. En el siguiente pasaje de Los nombres, Fatma se asoma a la ventana para tomar el aire y conectarse con el mundo; el flujo de deseo se presenta como el aire y aprendemos después que el aire se asocia con Kadiya:

Para algunos, su ventana abierta se veía aún más vacía cuando ella asomaba la cara. Sin embargo, para Fatma, la ventana no era la caja de sus nadas, como suponían al verla, sino la puerta que la conducía a todas las cosas y a ninguna. Era el estuche de donde tomaba la sed de todo, ya que todas esas ausencias volátiles que eran el aire de su melancolía, tenía raíces en las partes de su carne que más fácilmente atraviesa la imaginación. Raíces que tomaban su calor del vientre y su humedad de la piel. (42)

El deseo y su conexión sensual con el mundo no dependen en absoluto de una mirada foránea masculina, a no ser que se le imponga la de un lector. "Las partes” y las raíces afirman tanto la conectividad como la intensidad entre ella, su cuerpo, y el mundo a través del aire. La imaginación erótica aquí es suya y es producto y producción de su propio placer autoerótico. En lo que sigue las manos de ella se confunden con el aire para convertirse en otras manos que la acarician desde su interior:

Cuántas veces, sentada en su ventana, dejaba deslizar sus dedos sobre los labios, lentamente, de tal manera que ella misma ya no sabía si su dedo venía de un lado o del otro... El aire de mar que tomaba en la ventana era las manos que suavemente la iban tocando por dentro. Erguida iba llenando sus pulmones, abandonándose al aire para sentir su progresiva presión desde adentro....

Sus dedos suben y bajan todas las espirales de su cuerpo coincidiendo a cada momento con los otros dedos que la recorren por dentro. Ambos se reconocen a través de la piel como dos puntas de alfileres encendidos que recorren las dos superficies de una tela y donde se encuentran queman.

Los dedos del aire que tomaba en su ventana le daban a sus manos los poderes para encender su cuerpo. (42)

El plano de consistencia entre dedos, labios, aire y cuerpo conforma un espacio intensivo, relacionando unos estratos con otros como hemos visto en todas las imágenes metafóricas de la narrativa de Ruy Sánchez. El deseo fluye de manera que su cuerpo se integre al mundo, se confunda con el aire, se vuelva otro. Más adelante en Los nombres el narrador reafirma la ruptura entre interior y exterior cuando declara que Fatma "ya no sabía qué estaba adentro de ella y qué afuera” (65).

También en el hammam, sitio que emana deseo en donde los cuerpos se congregan y se moldean al lugar, cuando Fatma mira fijadamente a las espaldas de otras mujeres su

como Ruy Sánchez ha sabido evitar los escollos de la mirada masculina sobre la mujer, y especialmente sobre la mujer árabe. Y sobre todo cuando se trata de una mirada extranjera sobre ella, casi siempre percibida como objeto del deseo y de los fantasmas masculinos, y no como sujeto. Las mujeres en la obra de Ruy Sánchez son mujeres que desean desde antes de ser deseadas" ("Mogador, puente colgante"). 
cuerpo se entrega al flujo de las intensidades. Al mirar los cuerpos y muros del hammam, Fatma atestigua la integración y desintegración de la imagen de su cuerpo en una multiplicidad colectiva que recuerda otra vez la novela como rizoma o ensambladura:

Los muros estaban cubiertos de mosaicos pintados con grecas y trazos voluptuosos que en todo se acomodaban a los pliegues más recónditos de los cuerpos, convirtiéndose en su eco infinito. Ya no ocultándolos sino descomponiendo su existencia y multiplicando sus secretos: confundiendo a los cuerpos con sus imágenes, otorgándoles una extensión más sutil que su propia sombra. Fatma dejó que su mirada se hundiera en los huecos dibujados en la pared, que ya eran sus propios huecos, humedeció la ondulación de sus cabellos en el agua de una fuente, y fue tomando sobre toda la piel empapada los reflejos que antes sólo brillaron en los mosaicos. (Los nombres 52)

Se trata del cuerpo sin órganos precisamente porque se pierde la imagen del cuerpo diferenciado; un nuevo plano de consistencia, o mecanoesfera, se forma entre los cuerpos, sus pliegues y las grecas y trazos de los mosaicos. Otros planos de consistencia: miradahuecos dibujados, cabellos y agua, piel mojada y reflejo de mosaico. La belleza, el valor estético y espiritual del lugar es esta integración de lugar y cuerpo que produce sensualidad. Fatma se multiplica en los deseos de los demás, en el deseo colectivo que fluye por el hamman. Se vuelve un cuerpo entre otros, unos pliegues y cabellos entre otros. Su mirada se hunde en el lugar y su cuerpo toma los reflejos del lugar; la imagen de su cuerpo se dispersa y se integra en el lugar. ${ }^{5}$

Lo mismo ocurre en Los jardines cuando el ojo se pierde en el paraíso laberíntico de una mano tatuada de jena. Para encontrar cada jardín el narrador se convierte en un cuerpo sin órganos; tiene que perderse en las sensibilidades de otros, aprender a asociar nuevos elementos en nuevos planos de consistencia. Deja que los deseos de los demás fluyan por él mismo, que se desterritorialicen en su voz: antes de que pueda volver a disfrutar el cuerpo de Jassiba, tiene que encontrar nuevas maneras de conectarse con el mundo sensual de Mogador y después convertirse en voz poética para compartir lo que aprendió con Jassiba. Al convertirse en voz el narrador-poeta produce textos, proemas, que reproducen las intensidades que le ofrece a Jassiba, del mismo modo que se ofrece a sí mismo:

Así quisiera yo trazar en tu piel, Jassiba, la geometría secreta de nuestro paraíso. Una figura que sólo tú pudieras ver y descifrar en un lenguage inventado por nuestros cuerpos. [...] Quiero ser en tu piel la línea escrita de la felicidad. [...] Quisiera ser la jena que te cubre y que viene de ese lugar fuera del mundo que por un instante compartimos. (Los jardines 83-4)

\footnotetext{
${ }^{5}$ Lahrech ha examinado también el poder combinatorio del cuerpo y el alma en relación con El collar de la paloma de Ibn Hazm: "Las almas en las novelas de Ruy Sánchez son múltiples y fragmentas a la vez; los cuerpos son inhabitados por los deseos de otros. Y la fuerza atractiva de otros depende de una relación, no tanto un deseo de reintegración, como si hubiera una unión perdida, sino en las posibilidades múltiples de combinación, de renacimiento. El cuepro es fragmento y multiple a la vez" ("Mogador, puente colgante”).
} 
El proema en cursiva que se encuentra al final de cada capítulo de la segunda y tercera partes, más las fotografías y las caligrafías al final del libro, afirman la voz poética del narrador como parte de un cuerpo sin órganos, en el sentido de que producen flujos de intensidades precisamente en la formación de imágenes, sobre todo su propio discurso como imagen verbal que se eslabona con el tatuaje (plano de consistencia: mano tatuadomirada-oído-poema-escritura sobre la piel de Jassiba). También los proemas, caligrafías e imágenes fotográficas refuerzan la idea del libro como un cuerpo sin órganos que converge con otros libros/cuerpos sin órganos, siguiendo lo que dicen Deleuze y Guattari en el epígrafe de este estudio. En particular las tres novelas establecen fuertes relaciones intertextuales con El collar de la paloma: un tratado sobre el amor y los amantes por el tono de los proemas que se asemeja al de Ibn Hazm, y por El tratado invisible del amor, libro inventado del personaje el calígrafo Aziz Al Gazali, quien nos hace recordar, según Lahrech , "al famoso teólogo y místico Abu Hamid Muhamed al-Ghazali de los siglos xxI” (“Mogador, puente colgante”). Los jardines y En los labios también trazan múltiples líneas o vasos comunicantes con la primera novela de la serie Los nombres del aire. Por último, las tres novelas de Ruy Sánchez, por medio de la caligrafía de Hassan Massoudy y la sensualidad poética, rinden homenaje a la tradición poética hispano-árabe a la vez que brotan rizomas que comunican con los precursores y contemporáneos de Ruy Sánchez: con Deleuze en particular, pero también con Rumi, con Borges y con un sinnúmero de otros.

\section{Conclusión}

Los libros de Ruy Sánchez recuerdan tanto a las catedrales como a la caligrafía porque son cuerpos sin órganos. Las imágenes poéticas de las novelas refuerzan esta conexión; por ejemplo, cuando dos miradas que se cruzan "como los arcos de una bóveda diseñada tiempo atrás” (72), imagen que recuerda tal vez las bóvedas de crucería de la catedral, o cuando los dedos pálidos de Fatma y los muy oscuros de Kadiya hacen "crecer entre las dos un tupido bosque de ramas negras y blancas, entretejidas como ilegible caligrafía" (Los nombres 73).

Aprovechando su experiencia personal e intelectual en Marruecos y con Deleuze, Alberto Ruy Sánchez nos muestra una vía estética para apreciar la diferencia de la cultura árabe. A mi juicio, no se reduce ni al fetichismo, ni al canibalismo, sino que cumple con un deber, algo que Ortega reconoció que faltaba en la cultura hispana (prólogo a El collar de la paloma 11): Ruy Sánchez escribe un homenaje a la herencia hispano-árabe, ofeciéndonos así otra vía de comprensión y amor para con los pueblos del Magreb. También su escritura rinde homenaje a Deleuze al trazar múltiples líneas o vasos comunicantes con la obra del filósofo francés. De hecho, Ruy Sánchez afirma directamente la relación recíproca que tiene con el pensamiento de Deleuze, sobre todo con los libros Mil mesetas y Cínema. No sólo fue estudiante de Deleuze durante siete años, época en que éste escribió estos dos libros, sino que también fue su interlocutor contribuyendo a la producción intelectual de Deleuze, como lo explica en una entrevista personal:

Deleuze era muy impresionante también por su entrega. [...] Estaba toda su inteligencia, todo su pensamiento en cada clase. Al mismo tiempo las clases eran el laboratorio en el 
que se iban preparando los libros que estaba escribiendo. [...] En aquella epoca yo trabajaba mucho sobre Sergei Eisenstein; entonces yo le llevé los textos de Eisenstein donde hablaba del tema que a él le interesaba. Todo lo que sale en Mille plateaux y después en Cinéma sobre Eisenstein, pues, fue creado en diálogo conmigo y con otros estudiantes. Él iba sabiendo tomar sin robar, sino realmente en diálogo él era mucho más creativo que la mayoría de las personas a su alrededor. Él no solamente enseñaba lo que dijeron los otros, sino que lo hacía con su huella personal muy fuerte. Y en este sentido para mí fue modelo. (Stanford, 14 de junio, 2003)

La relación entre la obra de Deleuze y la de Ruy Sánchez también brota de un intercambio directo como se puede ver en la entrevista. Además de esta clara afinidad que resulta de la experiencia personal, en la escritura de Ruy Sánchez se trazan múltiples conexiones donde convergen las obras de los dos autores como cuerpos sin órganos; tienen puntos de contacto donde pasan intensidades, flujos, donde se enredan rizomas que se extienden en múltiples direcciones y obras. Pero la obra de Ruy Sánchez no puede reducirse a sólo esta lectura deleuziana, y nuestro autor parece advertirnos de esta trampa en esta última entrevista. Como hemos visto, Ruy Sánchez tiene otras afinidades también y su obra converge con las de una plétora de escritores. No obstante, la escritura de Ruy Sánchez potencia el discurso filosófico de Deleuze al reconfigurarlo a través de la tradición hispano-árabe y de sus lecturas preferidas. En la novelas de Ruy Sánchez los mismos principios y conceptos que se encuentran en el discurso de Deleuze se metamorfosean en un ámbito cada vez más poético e intertextual.

\section{BIBLIOGRAFÍA}

Deleuze, Gilles y Félix Guattari. L’Anti-Edipe: Capitalisme et schizophrénie. Paris: Minuit, 1972/1973.

Mil mesetas: Capitalismo y esquizofrenia. José Vázquez Pérez y Umbelina Larraceleta, trad. Valencia: Pre-Textos, 2004. Mille plateaux: Capitalisme et schizophrénie. Paris: Minuit, 1980. “Introducción”. Rizoma. C. Casillas y V. Navarro, trad. Según texto publicado por Pre-Textos de Valencia, España. México: Ed. Coyoacán, 2001.

Hazm de Córdoba, Ibn. El collar de la paloma. Emilio García Gómez, trad. Prólogo de José Ortega y Gasset. Madrid: Alianza, 1996.

Lahrech, Oumama Aouad. "Mogador, puente colgante entre las dos orillas del Atlántico”. Conferencia leída en Essaouira, durante la Tercera Sesión de La Universidad Convivial sobre el tema : Essaouira y la dimensión atlántica de Marruecos ( 5-8 de noviembre de 1998). 30 de agosto $2005<$ http://www.albertoruysanchez.com/>.

Lezama Lima, José. “Sierpe de Don Luis de Góngora”. Lezama Lima. Armando Alvarez Bravo, ed. La Paz: Jorge Alvarez, 1968. 191-220.

Martínez Martínez, Francisco José. Ontología y diferencia: la filosofía de G. Deleuze. Colección Ensayo y Pensamiento Filosófico. Madrid: Editorial Orígenes, 1987.

Paúl Arranz, María del Mar y María Luiza de la Garza Chávez. “Alberto Ruy Sánchez: Calígrafo del erotismo”. Revista Iberoamericana LXIV/187 (abril-junio 1999): 359371. 
Ruy Sánchez, Alberto. Al filo de las hojas. México, DF: SEP-Plaza y Valdés, 1988. Con la literatura en el cuerpo. Madrid: Taurus, 1995.

En los labios del agua. Madrid: Alfaguara, 1996. Los jardines secretos de Mogador: voces de tierra. México: Alfaguara, 2001. Los nombres del aire. Madrid: Alfaguara, 1987.

“Conferencia sobre Artes de México”. Consulado de México (San Francisco, 12 de junio de 2003). “Entrevista personal con Michael Abeyta” (Stanford, 14 de junio de 2003). "Geometrías del deseo: Entrevista con Alberto Ruy Sánchez". Angel Gurría Quintana. La Jornada Semanal (México, 3 de noviembre de 1996): 10-11.

Sarduy, Severo. "La emigración de los tatuajes”. Obras Completas Vol. II (1431-1434). Scavino, Dardo. Nomadología: una lectura de Deleuze. Buenos Aires: Ediciones del Fresno, 1991. 